\title{
THE
}

\section{Global evaluation of particulate organic carbon flux parameterizations and implications for atmospheric $\mathrm{pCO}_{2}$}

\author{
Lucas Gloege \\ Galen A. McKinley \\ Colleen B. Mouw \\ University of Rhode Island, cmouw@uri.edu \\ Audrey B. Ciochetto \\ University of Rhode Island
}

Follow this and additional works at: https://digitalcommons.uri.edu/gsofacpubs

\section{The University of Rhode Island Faculty have made this article openly available.} Please let us know how Open Access to this research benefits you.

This is a pre-publication author manuscript of the final, published article.

Terms of Use

This article is made available under the terms and conditions applicable towards Open Access Policy Articles, as set forth in our Terms of Use.

\section{Citation/Publisher Attribution}

Gloege, L., McKinley, G. A., Mouw, C. B., and Ciochetto, A. B. ( 2017), Global evaluation of particulate organic carbon flux parameterizations and implications for atmospheric $\mathrm{pCO}_{2}$, Global Biogeochem. Cycles, 31, 1192- 1215, doi: 10.1002/2016GB005535.

Available at: https://doi.org/10.1002/2016GB005535

This Article is brought to you for free and open access by the Graduate School of Oceanography at DigitalCommons@URI. It has been accepted for inclusion in Graduate School of Oceanography Faculty Publications by an authorized administrator of DigitalCommons@URI. For more information, please contact digitalcommons-group@uri.edu. 


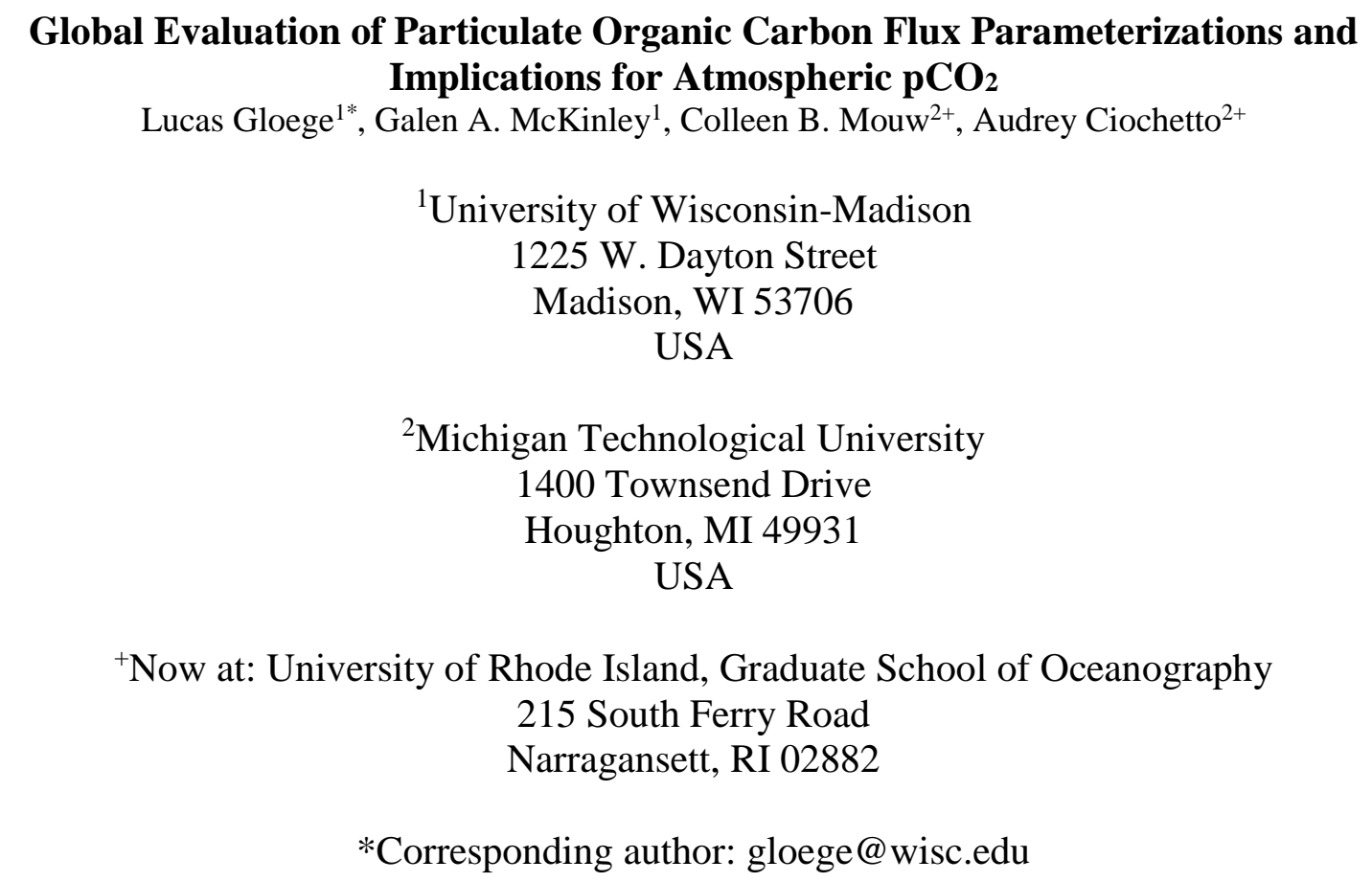

${ }^{+}$Now at: University of Rhode Island, Graduate School of Oceanography 215 South Ferry Road

Key words: Biological pump, POC flux, ballast hypothesis, Martin curve

\section{Key points:}

- Three parameterizations for particulate organic carbon (POC) export are compared to global data.

- POC fluxes estimated from the Martin curve and the ballast hypothesis capture observations equally well at all depths.

- Globally, data constrain Martin's $b$ to a range from 0.70 to 0.98 . This range could modify atmospheric $\mathrm{pCO}_{2}$ by only tens of ppm. 

$57+12 \mathrm{ppm}]$

\section{Abstract}

The shunt of photosynthetically derived particulate organic carbon (POC) from the euphotic zone and remineralization at depth comprises the basic mechanism of the "biological carbon pump." POC raining through the "twilight zone" (euphotic depth to $1 \mathrm{~km})$ and "midnight zone" (1 km to $4 \mathrm{~km})$ is remineralized back to inorganic form through respiration by heterotrophs and bacteria. Accurately modeling POC flux is critical for understanding the "biological pump" and its impacts on air-sea $\mathrm{CO}_{2}$ exchange and, ultimately, long-term ocean carbon sequestration. Yet, the parameterizations of POC flux commonly used in simulations have not been tested quantitatively against global datasets using the same modeling framework. Here, we use a single one-dimensional physical-biogeochemical modeling framework to assess the skill of three common POC flux parameterizations in capturing POC flux observations from moored sediment traps and thorium-234 depletion. The exponential decay, Martin curve, and ballast model are compared to data from 11 biogeochemical provinces distributed across the globe. In each province, the model captures satellite-based estimates of surface primary production within uncertainties. Goodness-of-fit is measured by how well the simulation captures the observations, quantified by bias and the root-mean-squared-error and displayed using "target diagrams." Comparisons are presented separately for the twilight zone and midnight zone. We find the parameterization based on the ballast hypothesis shows no improvement over a globally or regionally parameterized Martin curve. For all provinces taken together, Martin's $b$ that best fits the data is $[0.70,0.98]$; this finding reduces by at least a factor of 3 previous estimates of potential impacts on atmospheric $\mathrm{pCO}_{2}$ of uncertainty in $\mathrm{POC}$ export to a more modest range [-16 ppm, 


\section{Introduction}

60 The biologically-mediated removal of organic carbon from surface waters against a

61 dissolved inorganic carbon (DIC) gradient and its subsequent remineralization at 62 depth is termed the "biological pump" [Broecker and Peng, 1982; De La Rocha, 63 2006], which can be separated into a "carbonate pump" and a "soft-tissue pump" 64 [Volk and Hoffert, 1985] as well as a "microbial pump" [Jiao et al., 2010]. The percentage of net primary production (NPP) exported from the euphotic zone as particulate organic carbon (POC) is at least 5\%, with some estimates higher than $40 \%$ [Martin et al., 1987; Buesseler, 1998; Schlitzer, 2000; Boyd and Trull, 2007;

Buesseler and Boyd, 2009; Henson et al., 2011]. Much of this material is respired, primarily by bacteria and zooplankton, within the "twilight zone" (euphotic depth to $1000 \mathrm{~m}$ ) [Steinberg et al., 2008]; only 3\% of exported NPP reaches the $1000 \mathrm{~m}$ depth horizon [De La Rocha and Passow, 2007]. On timescales of days to weeks the flux of POC is controlled by sinking speed and degradation rate. If in steady state, POC flux should be balanced by the input of limiting nutrients to the euphotic zone [Passow and Carlson, 2012; Giering et al., 2017].

.

POC flux to depth is the hallmark of the biological pump, and is critical to setting surface ocean $\mathrm{pCO}_{2}$ [Parekh et al., 2006; Kwon et al., 2009; Kwon et al., 2011; DeVries et al., 2012]. The $\mathrm{pCO}_{2}$ gradient across the air-sea interface determines the direction of carbon flux across the surface. By converting DIC to organic carbon, biological activity reduces surface ocean $\mathrm{pCO}_{2}$ and promotes $\mathrm{CO}_{2}$ uptake by the ocean. The downward POC flux then sequesters carbon at depth. Changes in the

efficiency of the biological pump, measured as the ratio of exported POC to primary 
production has the potential to alter ocean carbon storage and atmospheric $\mathrm{CO}_{2}$ [Marinov et al., 2008a, 2008b; Kwon et al., 2009; Henson et al. 2011]. Parekh et al. [2006] estimate the atmospheric $\mathrm{pCO}_{2}$ would be 150-200 $\mu$ atm greater than the current value if not for the biological control on the vertical DIC gradient. Kwon et al. [2011] separate the sensitivity of atmospheric $\mathrm{CO}_{2}$ to changes in the carbonate pump versus the soft-tissue pump. They find that for a globally-averaged respired carbon increase of $10 \mu \mathrm{mol} \mathrm{kg}$, the carbonate pump increases atmospheric $\mathrm{CO}_{2}$ by about $3.4 \%$ while the soft-tissue pump decreases atmospheric $\mathrm{CO}_{2}$ by $5.3 \%$, thus there is a net $2 \%$ reduction in atmospheric $\mathrm{CO}_{2}$ when both pumps are accounted for.

Projections using earth system models show a sizeable uncertainty across various models with respect to the biological pump's response to 21 st century climate change [Bopp et al., 2013; Laufkötter et al., 2015; Hauck et al., 2015; Krumhardt et al. 2016]. Accurate estimation the sensitivity of the biological pump to future climate change is critical to economic evaluations of the impacts of climate change on ecosystem services [Barange et al., 2017]. Parameterizations used in earth system models would ideally capture both the mean POC attenuation and the variability found in available observations, and do so in a mechanistically-realistic manner, in order to reliably predict future change in the strength and efficiency of the biological pump.

Early parameterizations of POC flux relate export either at a reference depth [Martin et al., 1987] or the euphotic zone primary production [Suess, 1980; Betzer et al., 1984; Pace et al., 1987] to the vertical POC flux through an empirically-derived relationship. Although these parameterizations lack mechanistic realism, the Martin et al. [1987] power law parameterization, in some cases with adjustment to different 
ocean regions [Henson et al. 2012; Guidi et al. 2015], has been used widely to predict carbon flux >2000m [François et al., 2002; Honjo et al., 2008]. Alternative to a power law parameterization, an exponential curve has been used to describe attenuation through an empirical fit to observations [Lutz et al., 2002; Boyd and Trull, 2007; Marsay et al., 2015]. Parameterizations assuming first-order kinetics and a constant sinking speed have been used in biogeochemical models [Walsh et al., 1988; Banse, 1990; Dutkiewicz et al., 2005; DeVries and Weber, 2017], which implies an exponential decay of POC. More mechanistic parameterizations, such as those based on the "ballast hypothesis" [Armstrong et al., 2002] assume minerals associated with POC increase the POC flux at depth, have been proposed.

To directly compare the various choices available for POC parameterization, a global dataset with consistent treatment and a consistent model framework is required. The choice of seasonal normalization in datasets [Lutz et al., 2002; Lutz et al., 2007; Honjo et al., 2008] can impact statistical fits, and simulated POC fluxes are dependent both on the POC flux parameterization, and also on the simulated surface ocean productivity. In a previous model-data comparison, Howard et al. [2006] used a threedimensional ocean model in which surface NPP responds to the POC parameterization. They find that the ballast model captures observations more accurately than the Martin curve, and that the geochemical distribution in the deep ocean is sensitive to the parameterization used. However, there has not yet been a comparison across all three common parameterizations in which the modeling framework is identical, including identical surface NPP and POC production to drive the vertical fluxes estimated by each parameterization. 
133 In this study, we compare three common POC flux parameterizations using a single

134 one-dimensional numerical modeling framework in which NPP is not responsive to

135 the parameterization used; i.e. each parameterization is driven by the same surface

136 POC source. This model is applied in 11 Longhurst [2006] provinces for which

137 adequate POC flux data are available (Figure 1). We quantitatively evaluate, using a

138 suite of statistical tests, the exponential decay model, Martin curve, and the ballast

139 hypothesis against the recently released global POC flux dataset [Mouw et al., 2016a]

140 that consists of POC flux observations from sediment traps supplemented with

141 thorium-234 depletion observations (2\% of the data) spanning years 1976 to 2012.

143 2. Methodology

\section{$144 \quad 2.1$ Model Description}

145 The Massachusetts Institute of Technology general circulation model (MITgcm)

146 [Marshall et al., 1997a, 1997b] is configured as a one-dimensional column with 77

147 vertical layers. Depths increase from a resolution of $10 \mathrm{~m}$ in the surface to $650 \mathrm{~m}$ in

148 the deepest layer. K-profile parameterization (KPP) simulates vertical mixing [Large

149 et al., 1994]. The model uses a nutrient-restoring scheme with a relaxation time scale

150 of 30 days to approximate advection and diffusive processes that are not directly

151 simulated. Nutrients are restored towards the climatology appropriate for each

152 province in the euphotic zone when the simulated nutrient concentration falls below

153 the climatological value, while nutrients below the euphotic zone are constantly

154 restored towards climatology. Sediments are not included in the model, and thus

155 detritus slowly accumulates in the bottom grid cell; the bottom grid cell is ignored in

156 analyses.

157 
The model is initialized with physical and biogeochemical observations and forced at

159 the surface with monthly climatological meteorological and radiative fields

160 appropriate for each province. Temperature, salinity, and nutrients are prescribed by

161 World Ocean Atlas 2013 [Boyer et al., 2013]. Alkalinity and DIC are prescribed

162 using GLobal Ocean Data Analysis Project (GLODAP) atlas [Key et al., 2004].

163 Photosynthetically active radiation (PAR) is prescribed using Sea-viewing WIde

164 Field-of-view Sensor (SeaWIFS) data [Frouin et al., 2002]. Surface dust deposition

165 is provided by Mahowald et al. [2005]. Surface wind stress is prescribed using

166 National Center for Environmental Prediction (NCEP) reanalysis 1 [Kalnay et al.,

167 1996].

168

169 The ecosystem model embedded in MITgem is that of Dutkiewicz et al. [2005]. The

170 model includes two phytoplankton functional groups (diatoms and small

171 phytoplankton) and one zooplankton class. Phytoplankton growth can be light and

172 nutrient limited. Mortality rate and maximum growth rates of diatoms and small

173 phytoplankton are tuned for each province (supplementary Table S1) to best fit

174 satellite-based estimates of primary productivity (Table 1). The remineralization rate

$175(k)$ is set to $1 / 10 \mathrm{~d}^{-1}$ for POC and $1 / 150 \mathrm{~d}^{-1}$ for biogenic silica (opal). The dissolution

176 rate for particulate inorganic carbon (PIC) is $1 / 300 \mathrm{~d}^{-1}$. The sinking speed $(w)$ for

177 POC, PIC, and opal are fixed constants: POC and opal sink at a rate of $10 \mathrm{~m} \mathrm{~d}^{-1}$ while

178 PIC sinks at $15 \mathrm{~m} \mathrm{~d}^{-1}$. These POC sinking speeds lie within the range of other

179 models, $2.5 \mathrm{~m} \mathrm{~d}^{-1}$ [Yool et al., 2010], $8 \mathrm{~m} \mathrm{~d}^{-1}$ [Dutkiewicz et al., 2005], 11-85 $\mathrm{m} \mathrm{d}^{-1}$

180 [DeVries and Weber., 2017]. The POC remineralization rate and sinking speed used

181 here imply a remineralization length scale $\left(\lambda=w k^{-1}\right)$ of $100 \mathrm{~m}$, similar to the Lima

182 et al. [2014] value of $130 \mathrm{~m}$ and within the range assumed by Moore et al. [2004]. 
183 This remineralization length scale is within the 50-200 m range that Mouw et al.

184 [2016b] found for most provinces, and the 69-265m range derived from the

185 optimization of DeVries and Weber [2016].

186

187 The model assumes $7 \%$ of phytoplankton are calcifiers, and therefore produce PIC.

188 Production of POC, PIC, and opal are due to mortality of phytoplankton and

189 zooplankton, as well zooplankton grazing on phytoplankton. The tendency of POC,

190 PIC, and opal production are shown below:

$$
\frac{d\left[X^{\text {prod }}(z)\right]}{d t}=P_{X}^{\text {prod }}(z)+Z_{X}^{\text {prod }}(z)
$$

192 where $\mathrm{X}=\mathrm{POC}$, PIC, or opal. $P_{X}^{\text {prod }}(z)$ represents production of $\mathrm{X}\left(\mathrm{mgX} \mathrm{m}^{-2} \mathrm{~d}^{-1}\right)$ at depth $(\mathrm{z}, \mathrm{m})$ by phytoplankton $(\mathrm{P})$ and $Z_{X}^{\text {prod }}(z)$ represents production of $\mathrm{X}\left(\mathrm{mgX} \mathrm{m}{ }^{-2}\right.$ $\left.\mathrm{d}^{-1}\right)$ at depth $(\mathrm{z}, \mathrm{m})$ by zooplankton $(\mathrm{Z})$.

A 10-year simulation is run after a 10-year model spin up. The model uses a time step of 200 seconds with an 8-day averaging period. This averaging period is chosen to coincide with the time step of the vertically integrated production model (VGPM) [Behrenfeld and Falkowski, 1997] which is used for comparison to modeled NPP.

200 VGPM satellite-based NPP estimates are obtained from

201 http://www.science.oregonstate.edu/ocean.productivity/ and the modeled NPP is calculated as the integrated productivity in the euphotic zone.

\subsection{Exponential Decay Model}

205 The exponential decay model assumes that all the POC is labile with a constant 206 sinking speed, expressed in equation (2) [Banse, 1990]. 


$$
F(z)=w_{p o c}[\operatorname{POC}(z)]
$$

208 where $F(z)$ is the POC flux $\left(\mathrm{mgC} \mathrm{m}^{-2} \mathrm{~d}^{-1}\right)$ at depth $(\mathrm{z}, \mathrm{m}), w_{\text {poc }}$ is the sinking speed 209 of labile POC $\left(\mathrm{m} \mathrm{d}^{-1}\right)$, and $[P O C(z)]$ is the volume concentration of labile POC $(\mathrm{mgC}$

$210 \mathrm{~m}^{-3}$ ) at depth. The tendency of POC to sink and remineralize is expressed in the

211 following form:

$$
\frac{d[\operatorname{POC}(z)]}{d t}=w_{p o c} \frac{d[\operatorname{POC}(z)]}{d z}-k_{p o c}[\operatorname{POC}(z)]
$$

where the first term represents vertically sinking POC while the second term represents a first-order remineralization scheme where POC is instantly remineralized at each depth level (z) with $k_{p o c}$ being the remineralization rate. An expression for the flux of labile POC is derived by applying equation (2) to a steady state version of equation (3): $F(z)=F\left(z_{o}\right) \operatorname{EXP}\left[\left(z-z_{o}\right) / \lambda\right]$, where $F\left(z_{o}\right)$ is the flux at reference depth $z_{o}$ and $\lambda=\frac{w_{p o c}}{k_{p o c}}$ is the remineralization length scale (e-folding length scale). Table 2 provides definitions of all equation parameters.

The ecosystem model of Dutkiewicz et al. [2005] treats particulate organic matter as exponentially decaying throughout the water column and assumes all POC is labile. The full tendency of POC is defined in equation (4):

$$
\frac{d[\operatorname{POC}(z)]}{d t}=\frac{d\left[\operatorname{POC}^{\text {prod }}(z)\right]}{d t}+w_{\text {poc }} \frac{d[\operatorname{POC}(z)]}{d z}-f_{T} k_{\text {poc }}[\operatorname{POC}(z)]
$$

where the first term is the tendency of POC production (equation (1)) and the last two terms represent sinking and remineralization (equation (3)). Temperature dependence on remineralization rate is taken into account through an Arrhenius function: $f_{T}=A *$ $E X P\left[T_{A E}\left(T^{-1}-T_{r e f}^{-1}\right)\right]$, where $A, T_{A E}$, and $T_{r e f}$ are constants and $T$ is the local temperature (supplementary Table S2). POC flux at each level is calculated using 
equation (2). This framework will be termed the "exponential decay model" for POC

231 flux.

\subsection{Martin Curve}

234 Using data obtained from free-floating sediment traps, Martin et al. [1987] describe

235 POC flux attenuation using a normalized power function of the following form,

236 commonly referred to as the "Martin curve":

$$
F(z)=F(100)\left(\frac{z}{100}\right)^{-b}
$$

where $F(100)$ is the POC flux at $100 \mathrm{~m}$ and $b$ is the flux attenuation coefficient. The

239 Martin curve is equivalent to a decreasing remineralization rate with depth or an

240 increasing sinking speed with depth [Lam et al., 2011]. Villa-Alfageme et al. [2016]

241 observed an increase in sinking speed with depth, possibly due to the gradual loss of

242 slow-sinking particles with depth. Small values of $b$ imply a higher transfer

243 efficiency where more carbon remineralizes at deeper depths. Transfer efficiency is

244 defined as the fraction of exported organic matter that reaches a given depth below

245 the depth of export, with $100 \mathrm{~m}$ below the depth of export being where transfer

246 efficiency is typically estimated [Buesseler and Boyd, 2009]. Transfer efficiency and

$247 \quad b$ are inversely related: large values of $b$ imply a small transfer efficiency with more

248 carbon remineralizing at shallower depths. Martin et al. [1987] calculated a global $b$

249 value of 0.858 using observations from nine locations in the Northeast Pacific.

250 Regional variations in the $b$ parameter have been found to improve the statistical fits

251 at the scale of ocean provinces [Henson et al., 2012; Guidi et al., 2015] and across

252 ocean basins [Berelson, 2001; Schlitzer, 2002], implying regional variability in the

253 flux attenuation and transfer efficiency. Marsay et al. [2015] showed the $b$ parameter,

254 and hence the flux attenuation, correlates with temperature. This pattern is plausibly 
explained by a slowdown of microbial utilization of carbon as temperature decreases [Pomeroy and Diebel, 1986; Pomeroy et al., 1991]. Changes in $b$, when applied globally in a biogeochemical model, have been shown to significantly impact atmospheric $\mathrm{CO}_{2}$ concentrations [Kwon et al., 2009].

260 In this study, POC fluxes at depth based on the Martin curve are calculated offline 261 from surface production in MITgcm. In keeping with the original intent of the Martin curve, we use equation (5) to calculate the flux at each depth level (z) using an export depth of $100 \mathrm{~m}$ and export flux, $F\left(z_{100}\right)$, from the exponential decay model runs.

264 Due to nutrient restoring below the euphotic zone, feedback of shallow 265 remineralization on surface production is negligible; thus, this approach is robust. 266 Runs with both the Martin et al. [1987] global $b$ value of 0.858 as well as the Guidi et al. [2015] and Henson et al. [2012] regional $b$ values are performed for comparison.

\subsection{Ballast Hypothesis}

270 The ballast hypothesis proposed by Armstrong et al. [2002] asserts that "ballast" 271 minerals (PIC, opal, and dust), qualitatively associated with POC, increase the deep 272 ocean POC flux. Using observations from the equatorial Pacific, Armstrong et al. 273 [2002] observed that the ratio of organic carbon flux to total mass flux was nearly 274 constant below $1800 \mathrm{~m}$ and concluded ballast minerals are intimately related to the 275 POC flux. Mechanistically, the role of ballast minerals is not entirely clear. It has 276 been proposed that they act to increase the sinking speed and/or protect POC from 277 microbial respiration and zooplankton grazing. Thus, POC that is associated with 278 ballast minerals induces a higher transfer efficiency, delivering more POC to depth. 279 The ballast hypothesis asserts that sinking POC is a composed of "free" and ballast 
mineral associated fractions (supplementary Figure S1). The free fraction has a

281 remineralization length scale as labile POC while POC qualitatively associated with

282 ballast minerals is partitioned between a "soft" and "hard" subclass, which represent

283 external and internal protection mechanisms, respectively [Armstrong et al., 2002].

284 External protection constitutes physical removal from hydrolyzing enzymes by

285 adsorption of POC into mineral micropores and increasing sinking speed [Mayer,

286 1994]; POC associated with the soft fraction has the same remineralization profile as

287 its associated ballast mineral. Internal protection occurs when POC is encased in PIC

288 or opal, sheltering it from degradation until the mineral has dissolved [Armstrong et

289 al., 2002; and references therein]. For this reason, the hard fraction has a very deep

290 remineralization length scale, representing refractory POC. However, Iversen and

291 Robert [2015] concluded that ballast minerals act only to increase sinking speed and

292 do not provide any protection to organic matter.

294 Klaas and Archer [2002] used a global dataset of sediment trap observations in the

295 midnight zone to distinguish three forms of ballast with the following carrying

296 capacities (grams of organic carbon per gram of ballast): PIC (0.094), opal (0.025),

297 and dust (0.035). Additionally, Klaas and Archer [2002] observed 80\% of the POC

298 flux to the seafloor was associated with PIC, suggesting it is a more efficient ballast

299 mineral compared to opal and dust. There are three reasons why the carrying capacity

300 of PIC has been suggested to be greater than that of opal and lithogenic dust:

301 1. PIC sinks $\sim 50 \%$ faster than opal for an equivalent particle radius [Sarmiento

302 and Gruber, 2006], since the density of PIC $\left(2.71 \mathrm{~g} \mathrm{~cm}^{-3}\right)$ is $\sim 30 \%$ greater than

303 the density of opal $\left(2.1 \mathrm{~g} \mathrm{~cm}^{-3}\right)$ [Klaas and Archer, 2002]. 
2. Opal production and export is not as spatially uniform as PIC production and export [Sarmiento and Gruber, 2006]. The ratio of opal flux to carbon flux also varies regionally [Ragueneau et al., 2000 Figure 5].

3. Lithogenic fluxes are generally too small to significantly impact the transfer efficiency of organic carbon [François et al., 2002].

However, some studies find evidence that does not support PIC having a higher carrying capacity compared to opal or dust [De La Rocha et al., 2008] or show regional variability in the carrying capacity of each ballast mineral [Wilson et al., 2012; Pabortsava et al., 2017].

314 Published parameterizations for the ballast hypothesis have important differences: 315 Moore et al. [2004] and Armstrong et al. [2002] include PIC, opal, and lithogenic 316 material (dust) as ballast minerals while Yool et al. [2010] and Dunne et al. [2013] 317 omit ballasting from dust. The reader is referred to Moore et al. [2004] and Lima et 318 al. [2014] for a detailed description of the implementation of the ballast hypothesis in 319 a three-dimensional ocean model with dust.

321 For this study, the ecosystem model of Dutkiewicz et al. [2005] is augmented to 322 include ballasting from PIC, opal, and dust in a manner similar to that of Moore et al. 323 [2004] and Lima et al. [2014]. The implementation of the ballast hypothesis is based 324 on Armstrong et al. [2002] and assumes a portion of the POC production is associated 325 with PIC and opal production and surface dust deposition. Flux of POC is calculated 326 by multiplying the sinking speed by the concentration of POC associated with each 327 mineral (equation (6)): 


$$
\begin{aligned}
F(z) & =w_{\text {poc }}[\operatorname{POC}(z)]+w_{\text {pic }}\left[\operatorname{POC}_{P I C}(z)\right]+w_{\text {opal }}\left[\operatorname{POC}_{\text {opal }}(z)\right] \\
& +w_{\text {dust }}\left[P O C_{\text {dust }}(z)\right](6)
\end{aligned}
$$

330 where $w_{X}$ is the sinking speed of $\mathrm{X}=\mathrm{POC}, \mathrm{PIC}$, opal, or dust, $\left[P O C_{Y}(z)\right]$ is the 331 concentration of POC associated with $\mathrm{Y}=\mathrm{PIC}$, opal, or dust, and $[P O C(z)]$ is the 332 concentration of free or labile POC. The tendency of POC associated with ballast 333 mineral $\mathrm{Y}$ is separated into a hard and soft subclass (equation (7)):

$$
\frac{d\left[P O C_{Y}(z)\right]}{d t}=\frac{d\left[P O C_{Y}^{\text {soft }}(z)\right]}{d t}+\frac{d\left[P O C_{Y}^{\text {hard }}(z)\right]}{d t}
$$

POC in the soft subclass decays exponentially with a remineralization rate as its associated ballast mineral while POC in the hard subclass decays exponentially with a very long remineralization rate; POC in each subclass has the same sinking speed as

338 its associated ballast mineral. Each term in $\frac{d\left[P O C_{P I C}(z)\right]}{d t}$ is defined in Table 3 and each 339 term in $\frac{d\left[\mathrm{POC}_{\text {opal }}(\mathrm{z})\right]}{d t}$ is defined in Table 4. The source of dust in the model is from 340 surface deposition (dust ${ }^{\text {dep }}, \mathrm{mgDust}^{-2} \mathrm{~d}^{-1}$ ). POC associated with dust solely 341 occurs in the surface grid cell $\left(\Delta z_{\text {surf }}, m\right)$ and is separated into a hard and soft 342 subclass which decay exponentially. Each term in the tendency equation for POC 343 associated with dust $\left(\frac{d\left[P O C_{d u s t}(z)\right]}{d t}\right)$ is defined in Table 5. The tendency of free POC 344 production is calculated by subtracting ballast associated POC from the total POC 345 production: $\frac{d\left[\text { POC }_{\text {free }}^{\text {prod }}(z)\right]}{d t}=\frac{d\left[\text { POC }^{\text {prod }}(z)\right]}{d t}-\left[\omega_{P I C}\left(\frac{d\left[\text { PIC }^{\text {prod }}(z)\right]}{d t}\right)+\right.$ $\left.346 \omega_{\text {opal }}\left(\frac{d\left[\operatorname{opal}^{\operatorname{prod}}(z)\right]}{d t}\right)+\omega_{\text {dust }}\left(\frac{d u s t^{\text {dep }}}{\Delta z_{\text {surf }}}\right)\right]$, where $\frac{d\left[X^{\operatorname{prod}}(z)\right]}{d t}$ is the production of $347 \mathrm{X}=\mathrm{PIC}$ or opal by phytoplankton and zooplankton (equation (1)) and $\omega_{Y}$ is the POC 348 carrying capacity for $\mathrm{Y}=\mathrm{PIC}$, opal, or dust. Each term in the tendency equation for 349 free POC $\left(\frac{d[P O C(z)]}{d t}\right)$ is defined in Table 6. 


\subsection{Analysis}

352 An 8-day climatology of POC flux within each province is created using the Mouw et al. [2016a] data compilation of in situ sediment trap and thorium-234 based measurements. PIC and opal fluxes are not analyzed due to insufficient spatial and temporal resolution in the field data. Dates are converted to day of year and aligned in time using the midpoint of the deployment. POC flux observations within each biogeochemical province as defined by Longhurst [2006] (provided by VLIZ [2009]) are aggregated and grouped by depth and day of year into 8-day segments.

Observations are then aggregated to the model vertical grid in order to quantitatively

360 compare to model output. In order to be considered in our comparison, observations

361 must be available at depths greater than $1000 \mathrm{~m}$ and the model must capture the

362 surface ocean production in a manner consistent with satellite retrievals. Coastal 363 provinces are omitted.

365 Model performance is assessed by investigating the model-data misfit, defined as $366 \Delta(i)=\log [M(i)]-\log [O(i)]$ where $M(i)$ and $O(i)$ represent the $\mathrm{i}^{\text {th }}$ model 367 prediction and $\mathrm{i}^{\text {th }}$ observed value respectively. Each observation is log base 10 368 transformed to alleviate skewedness from large values. The water column is 369 partitioned into the twilight zone (100-1000m) and midnight zone (1000-4000m), 370 with each analyzed separately. For consideration of variability, the full range of 371 variability for the model and observations across each zone is compared. A set of six 372 summary statistics are used as univariate measures of model performance [Stow et al., 373 2009]: 
1. Correlation: $\quad r=\frac{\sum_{i=1}^{N}\{\log [M(i)]-\overline{\log [M(l)]}\}\{\log [O(i)]-\overline{\log [O(l)]}\}}{1}$ $\left\{\sum_{i=1}^{N}[M(i)-\bar{M}]^{2} \sum_{i=1}^{N}[O(i)-\bar{O}]^{2}\right\}^{\frac{1}{2}}$

2. Root Mean Squared Difference: $\quad R M S D=\left[\frac{1}{N} \sum_{i=1}^{N} \Delta(i)^{2}\right]^{\frac{1}{2}}$

3. Bias: $\quad B=\overline{\log [\mathrm{M}(\mathrm{l})]}-\overline{\log [\mathrm{O}(\mathrm{l})]}$

4. Average Absolute Error: $\quad A A E=\frac{\sum_{i=1}^{N}|\log [\mathrm{M}(\mathrm{i})]-\log [\mathrm{O}(\mathrm{i})]|}{N}$

5. Model Efficiency: $\quad M E=1-\frac{\sum_{i=1}^{N}\{\log [\mathrm{M}(\mathrm{i})]-\log [\mathrm{O}(\mathrm{i})]\}^{2}}{\sum_{i=1}^{N}\{\log [\mathrm{O}(\mathrm{i})]-\overline{\log [\mathrm{O}(\mathrm{l})]}\}^{2}}=1-\left(\frac{R M S D}{s_{O}}\right)^{2}$

6. Reliability index: $\quad R I=10^{R M S D}$

380 The correlation ( $r$ ) is a measure between -1 and 1 quantifying the degree to which the 381 simulation and observations linearly vary. The correlation only expresses how well 382 the simulation and observations vary together and does not account for systematic 383 biases; a correlation of 1 does not preclude a mean offset between the simulation and 384 observations. Additionally, this value is related to the coefficient of determination $385\left(\mathrm{r}^{2}\right)$, which expresses the variance explained by a linear regression.

Root mean squared difference (RMSD), bias (B), and average absolute error (AAE) are all measures of the discrepancy between the simulated and observed mean. Values near zero imply “good” model performance and large values imply "poor” 390 model performance using these metrics. The modeling efficiency (ME) can be used 391 as a transition value between good and poor model performance [Nash and Sutcliffe, 392 1970]. A skillful model by this metric has an ME value near one. Modeling 393 efficiency is related to RMSD: $M E=1-\left(\frac{R M S D}{s_{O}}\right)^{2}$, where $s_{O}$ is the observed 394 variance. The reliability index (RI) quantifies the average factor by which the model 395 differs from observations. For example, an RI of 2 implies the model predictions 396 need to be multiplied by 2 in order to reconstruct the observations. 
398 Model performance is visualized using normalized "target diagrams" [ Jolliff et al.,

399 2009]. Target diagrams visualize bias and variability together (Figure 2a), giving

400 them an advantage over the commonly used "Taylor diagram" [Taylor, 2001], which

401 summarizes only the variability. Normalized target diagrams are based on the

402 following quadratic relationship:

$$
\left(\frac{R M S D}{s_{O}}\right)^{2}=\left(\frac{B}{s_{O}}\right)^{2}+\left(\frac{u R M S D}{s_{O}}\right)^{2}
$$

404 where $u R M S D=\frac{1}{N} \sum_{i=1}^{N}[\Delta(i)-B]^{2}$ is the unbiased RMSD (or variance of the 405 model-data misfit), which measures the degree to which the model captures the 406 observed variance, bias (B) is a measure of how well the simulated mean captures the 407 observed mean, and $s_{O}$ is the observed variance. Target diagrams provide a novel 408 way of visualizing B and uRMSD on a single plot: bias (B) on the y-axis and 409 unbiased RMSD (uRMSD) on the x-axis. The radial distance, $\left(\frac{R M S D}{s_{O}}\right)^{2}$, is related to 410 the modeling efficiency (ME): $\left(\frac{R M S D}{s_{O}}\right)^{2}=1-M E$. ME is negative when the radial 411 distance is greater than one and modeling efficiency is positive when the radial 412 distance is less than one. Therefore, ME is visualized by plotting a circle with a 413 radius of one on a normalized target diagram; skillful models are within the circle. 414 Under- or over-estimation of the variability is quantified by multiplying uRMSD by 415 the sign of the observed variance $\left(s_{O}\right)$ subtracted from the modeled variance $\left(s_{M}\right)$.

416 Equation (9) shows the relationship used to construct target diagrams presented in this 417 manuscript, which is equivalent to equation (8):

$$
(1-M E)=B^{* 2}+u R M S D^{* 2}
$$


where $B^{*}=\frac{B}{s_{O}}$ and $u R M S D^{*}=\frac{u R M S D}{s_{O}} \operatorname{sign}\left(s_{M}-s_{O}\right)$. Normalized target diagrams

420 allow the display of multiple models on a single plot. They also visualize how well

421 each model captures the observed mean and variance along with the modeling

422 efficiency (ME). Target diagrams have previously been used to assess satellite

423 derived NPP estimates [Friedrichs et al., 2009; Saba et al., 2010; Saba et al., 2011;

424 Lee et al., 2015], surface chlorophyll [Hofmann, 2008; Lazzari et al., 2012], and

425 physical variables such as temperature and salinity [Hofmann, 2008; Pairaud et al., $4262011]$.

428 The final component of our analysis is to determine the range of Martin's $b$ that is

429 globally consistent with POC flux observations; and then to use this range to constrain 430 previous estimates of the potential sensitivity of atmospheric $\mathrm{pCO}_{2}$ to uncertainty in 431 the biological pump [Kwon et al. 2009]. The normalized bias ( $\left.\mathrm{B}^{*}\right)$, the vertical axis in 432 normalized target diagrams, is our metric for best fit. As discussed in detail in section 433 3, the three parameterizations are better able to capture the observed mean POC flux 434 rather than POC flux variability, motivating the choice of $\mathrm{B}^{*}$ as a metric. For this 435 analysis, the model is run for each province with a range of $b$ values from 0.40 to 1.40 436 (with increments of 0.01), the range of $b$ from Kwon et al. [2009]. B* is calculated 437 using observations only in the midnight zone, and in both the midnight and twilight 438 zones. A particular value of $b$ "accurately" captures the observed mean if the B* for 439 that model is within the range $[-1,1]$ (supplementary Figure S2). The best-fit global $b$ 440 range is taken as the interquartile range of all province-specific $b$ values.

441 Atmospheric $\mathrm{pCO}_{2}$ as a function of $b$ is taken from the global 3-D biogeochemical 442 modeling study of Kwon et al. [2009]. In their most realistic model formulation 443 ("nutrient restoring”, Supplementary Text T1), biological productivity changed in 
response to export change and a constant rain ratio (PIC/POC) of 0.08 was used. For

445 our analysis, their results are digitized and interpolated with a cubic spline [Kwon et

446 al., 2009, their Figure 3c]. The change in atmospheric $\mathrm{pCO}_{2}$ (referenced to $\mathrm{pCO}_{2}$

447 with $b=0.858$ ) is then inferred from this curve for the range of $b$ values that we find to

448 best fit POC flux observations.

\section{Results}

451 Four biogeochemical provinces out of eleven are selected to be presented in the main 452 text since they span a range of latitudes (Figure 1). Simulated POC fluxes for each 453 parameterization in the selected provinces are shown alongside observations in Figure 4543 ; all provinces are presented in supplementary Figures S3-S16, and considered in the 455 discussion and conclusions. Two provinces, Eastern Pacific subarctic gyres (PSAE) 456 and North Atlantic drift (NADR), were selected for focus because of their expected 457 collocation with the study regions for the Exports Processes in the Ocean from 458 RemoTe Sensing (EXPORTS) field campaign that is presently being planned [Siegel 459 et al., 2016]. These sites also cover a range of ecosystem states. The simulated mean 460 annual primary production in each province captures the climatological range of mean 461 annual primary production, calculated using VGPM (Table 1). Although the model 462 does not fully capture the observed seasonality across some provinces (supplementary 463 Figure S17), it does capture the annual primary production, indicating the model is a 464 useful tool to study mean annual export, as done here.

\subsection{Twilight Zone}

467 For each province, the Martin curve, exponential model, and ballast hypothesis have 468 similar reliability indexes in the twilight zone (Figure 4), illustrating that these 
parameterizations capture observations equally well within the twilight zone. This corroborates Buesseler and Boyd [2009], who show that the Martin curve and exponential model capture observations at shallow depths. The exponential decay model has a tendency to underestimate the flux deep in the twilight zone in some provinces such as the Pacific Equatorial Divergence (PEQD) (Figure 3). The exponential model assumes a constant sinking speed and remineralization rate (i.e. constant remineralization length scale) throughout the water column, which often results in fluxes that decrease too quickly with depth [Armstrong et al., 2002; Lutz et al., 2002]. The amount of variability in the modeled flux varies between provinces, much due to variability in primary production.

The interquartile ranges for the three parameterizations overlap for each of the univariate statistics (Figure 5), quantitatively supporting that these parameterizations are equally good at capturing observations in the twilight zone. However, the parameterizations tend to underestimate the observed variability in the twilight zone, 484 evident through negative uRMSD* values (Figure 6). Depending on the location, the models either show a slight positive or negative bias (Figure 5, Figure 6). Overall, all the models perform well in the twilight zone and are more skillful than simply setting the POC flux to be the observed average (Figure 6).

\subsection{Midnight Zone}

490 The Martin curve and ballast hypothesis each capture observations well in the

491 midnight zone, while the exponential model underestimates the observed flux at these

492 depths (Figure 3; Figure 4). The exponential model underestimates the flux at depth 493 since a constant remineralization length scale does not allow for slowdown of 
494

remineralization with depth or increasing sinking speed with depth. The global Martin curve slightly underestimates the observed flux in some provinces, such as PEQD (Figure 3), resulting from either too low POC fluxes out of the euphotic zone or the use of a $b$ parameter that is too large.

In the midnight zone, the interquartile range for summary statistics overlap for both the Martin curve and ballast hypothesis (Figure 5); however, not for the exponential model. Each summary statistic suggests the exponential model performs poorly in the midnight zone compared to the Martin curve and ballast hypothesis:

1. Correlation interquartile range nearly symmetric about zero.

2. Large RMSD, AAE compared to Martin curve and ballast hypothesis.

3. Large negative bias compared to Martin curve and ballast hypothesis.

4. Large negative ME, suggesting poor model performance.

The exponential model for the midnight zone generally lies far from the origin in the fourth quadrant in the target diagram (Figure 6), consistent with its underestimate of the observed mean and overestimate of variability. However, if only one depth level is resolved in the midnight zone then the normalized target diagram suggests the exponential model reasonably captures the variability while underestimating the mean (e.g. PSAE). For all provinces, the Martin curve and ballast hypothesis both have a radial distance near unity on the normalized target diagram (Figure 6), suggesting these models are equally skillful.

\subsection{Regional Attenuation Parameter}

Regional Martin curves, using attenuation parameters from Henson et al. [2012] and Guidi et al. [2015], qualitatively agree with each other and with the global $b$ estimates 
519 (Figure 7, Figure 8). Regional $b$ parameters can lead to an improved fit in the 520 midnight zone in specific provinces. For example, the Guidi et al. [2015] regional $b$

521 parameter reduces the bias in PEQD relative to the Martin et al. [1987] global $b$ value

522 (Figure 2). This is further supported by the reliability index (RI) in the midnight zone 523 decreasing from 2.24 using Martin et al. [1987] global $b$ value to 1.97 using the Guidi 524 et al. [2015] regional $b$ parameter (Figure 8). However, when all 11 provinces are 525 considered, the interquartile range for each summary statistic overlaps (Figure 5), 526 which suggests on a global scale regional $b$ values produce no statistically significant 527 improvement over the Martin et al. [1987] global $b$ value.

\section{Discussion}

530 We use a consistent modeling framework to compare estimates of vertical POC flux 531 from three common parameterizations to a globally distributed dataset. We find that 532 the Martin curve and the ballast hypothesis capture observations equally well at all 533 depths. The exponential model is as skillful as the Martin curve and the ballast 534 hypothesis in the twilight zone (100-1000m), but not as skillful in the midnight zone 535 (1000-4000m).

Vertical attenuation of POC flux is ultimately controlled by particle sinking speed and 538 remineralization rate, each of which can change as the particle descends through the 539 water column. Potential processes influencing sinking speed and remineralization 540 rate include: mineral ballasting [Armstrong et al., 2002; François et al., 2002], 541 temperature [Laws et al., 2000; Marsay et al., 2015; DeVries and Weber, 2017], 542 oxygen concentration [Devol and Hartnett, 2001; Van Mooy et al., 2002; Keil et al., 543 2016; Sanders et al., 2016; DeVries and Weber, 2017], and particle aggregation [Burd 
and Jackson, 2009]. Some of these processes have been explicitly parameterized into

545 the "stochastic, Lagrangian aggregate model of sinking particles (SLAMS)", which

546 was able to reproduce sediment trap observed POC fluxes and some of its regional

547 variation [Jokulsdottir and Archer, 2016]. The relative and global importance of

548 these processes is unclear [Burd et al., 2016] and their influence on sinking speed is

549 still an active area of research. For example, Mari et al., [2017] show transparent

550 exopolymer particles (TEP) accumulates in the surface microlayer and needs to be

551 ballasted to overcome its low density in order to promote aggregation, which brings

552 into question the classic view that TEP increases POC flux by promoting aggregation

553 through its role as a "biological glue." Attenuation of POC flux is also effected by

554 surface processes that modify the character and lability of the POC that is exported.

555 For example, episodic events [Lebrato et al., 2012; Smith et al, 2014], community

556 structure [Guidi et al., 2009; Guidi et al., 2016], and zooplankton processes [Giering

557 et al., 2014; Cavan et al., 2015; Cavan et al., 2017; Steinberg and Landry, 2017] are

558 all likely important.

559

560 That we find that this implementation of the ballast hypothesis captures observations

561 in the twilight zone and midnight zone no better than the global and regional Martin

562 curves does not invalidate the ballast hypothesis. It simply indicates that the

563 interaction of ballast minerals with POC, as parameterized using standard approaches,

564 is not necessary to model POC flux in a manner that is statistically consistent with

565 observations from water column. A major issue here is, of course, the limited

566 coverage of these data in space and time [Mouw et al. 2016a,b; Siegel et al. 2016;

567 Burd et al. 2016]. The ballast hypothesis is based on a long-known correlation

568 between the flux of POC and the flux of ballast minerals [Deuser et al., 1981] which 
has been used to suggest ballast minerals are responsible for the flux of POC at depth,

570 either by increasing the sinking speed or protecting organic matter from oxidation

571 [Armstrong et al., 2002; François et al., 2002; Klaas and Archer, 2002]. The organic

572 matter content of sinking particles in the midnight zone is observed to be

573 approximately 5\% by weight [Armstrong et al., 2002]. An alternative view of this

574 correlation is that sinking POC scavenges neutrally-buoyant minerals [Passow, 2004],

575 which has been corroborated with a laboratory study [Passow and De La Rocha,

576 2006]. Additionally, Passow and De la Rocha, [2006] observed the POC to dry

577 weight percent concentration to be $2-3 \%$, which is similar to the $5 \%$ observed by

578 Armstrong et al. [2002] in deep sediment traps, suggesting this may be the carrying

579 capacity of suspended minerals for POC. Many studies support the claim that ballast

580 minerals increase the sinking speed of aggregates [De La Rocha and Passow, 2007;

581 Ploug et al., 2008; Iversen and Ploug, 2010]. However, the literature provides both

582 supporting [Arnarson and Keil, 2005; Engel et al., 2009; Le Moigne et al., 2013] and

583 opposing [Ingalls et al., 2006; Ploug et al., 2008; Iversen and Robert, 2015]

584 mechanistic evidence with respect to the degree to which ballast minerals protect

585 organic matter from oxidation.

\subsection{Modeling Recommendations}

588 Each parameterization investigated in this study may be useful in modeling studies,

589 but should be selected with consideration of the time and depth scales of interest. All

590 three parameterizations capture mean observations within the twilight zone and

591 therefore would be suitable for studies investigating the surface ocean on annual to

592 decadal time scales, i.e. where accurately capturing the deep ocean is not crucial.

593 However, for studies of the carbon cycle on centennial to millennial time scales, 
including assessments of long-term ocean carbon sequestration, carbon supply to the deep ocean should be important. In this case, the Martin curve and the ballast hypothesis capture observations at depth equally well on the mean and therefore

597 would both be suitable.

599 We find that the empirical Martin curve has a predictive power comparable to the 600 mechanistic ballast hypothesis, despite the fact that it lacks a mechanistic foundation.

601 Though regional variability in the $b$ parameter may improve the realism of the Martin 602 curve [Henson et al. 2012; Guidi et al., 2015], it is still not mechanistic. The 603 exponential decay model's first-order kinetics are mechanistic to a degree, but this 604 approach excludes suggested mechanisms such as increasing sinking speed and 605 remineralization length scale with depth [Villa-Alfageme et al., 2016]. The ballast 606 hypothesis is more mechanistic by allowing for refractory POC and allowing ballast 607 associated POC to sink faster with a longer remineralization length scale. However, 608 sinking speed and remineralization length scale of POC and ballast minerals still do 609 not increase with depth. Even though the ballast hypothesis is more mechanistic than

610 the exponential model and the Martin curve, it does not explain the observed

611 variability in POC flux at depth, which highlights a need for more complete

612 quantification of export mechanisms (see section 4). If simplicity is desired, our

613 recommendation would be to use the Martin curve in ecosystem models, but this 614 evaluation indicates that the ballast hypothesis would be an equally good choice.

616 In order to improve simulations of the biological pump, the relative significance of 617 mechanisms driving POC flux attenuation need to be better understood. The primary 618 limitation on this understanding is the lack of observational data with sufficient 
639

spatio-temporal resolution to resolve ecosystem processes in the surface ocean that generate POC and at the same time the processes driving remineralization at depth [Buessler and Boyd, 2009; Siegel et al. 2016; Burd et al. 2016]. Drivers of temporal variability in these mechanisms need also to be elucidated. To better constrain a model on seasonal timescales, having sediment trap data with higher temporal resolution and more sampling depths would be of great utility.

\subsection{Impacts on Atmospheric $\mathbf{p C O}_{2}$}

The biological pump plays an important role regulating atmospheric $\mathrm{pCO}_{2}[$ Parekh et al., 2006; Kwon et al., 2009] and may help explain the drawdown of atmospheric $\mathrm{pCO}_{2}$ during glacial periods [Sigman and Boyle, 2000; Buchanan et al., 2016] by sequestering carbon in the deep ocean [Yu et al., 2016]. Carbon raining to the "midnight zone" (>1000 m) can be considered sequestered because it will be out of contact with the atmosphere for at least 100 years [Primeau, 2005; Ciais et al., 2013]. Using earth system model experiments, Buchanan et al., [2016] find that the biological pump explains about $58 \%$ of the increase in atmospheric $\mathrm{pCO}_{2}$ from the last glacial maximum to pre-industrial times. The current uncertainty with respect to the biological carbon pump's role in setting atmospheric $\mathrm{pCO}_{2}$ has significant implications for our understanding of global climate regulation on time frames ranging from centennial to millennial.

Applying B* as a metric to limit Martin's $b$ to a range consistent with the observations in each province (section 2.6) reveals that Martin's global $b(=0.858)$ value is contained within the range of reasonable estimates for each province (Figure 9A). When data in the twilight zone and midnight zone are considered, and all 
644 provinces $b$ values collected, the interquartile range of $b$ values is $0.68-1.13$ (Figure

645 9C) while the range is $0.70-0.98$ when only considering observations solely in the

646 midnight zone (Figure 9D). The midnight zone contains $25-75 \%$ of observations in

647 each province (>33\% mean, Figure 9B) indicating sufficient data are available for the

648 latter comparison.

649

650 Thus, the best-fit global range for $b$ is $0.68-1.13$ across both the twilight and

651 midnight zone, and $0.70-0.98$ for only the midnight zone. These ranges are

652 substantially less than 0.4 to 1.4 used in the model of Kwon et al. [2009] to estimate

653 potential impacts on atmospheric $\mathrm{pCO}_{2}$. In their most realistic model configuration,

654 this range of $b$ leads to a range of equilibrium atmospheric $\mathrm{pCO}_{2}$ of almost $100 \mathrm{ppm}$ [-

$65546 \mathrm{ppm},+52 \mathrm{ppm}]$. Since only the carbon that reaches the midnight zone is

656 sequestered on the long-term, our data-constrained range of $b$ that is most applicable

657 to the control of atmospheric $\mathrm{pCO}_{2}$ is $0.70-0.98$. This constrained range leads to

658 change in atmospheric $\mathrm{pCO}_{2}$ from $-16 \mathrm{ppm}$ to $+12 \mathrm{ppm}$ in the Kwon et al. [2009]

659 model (supplementary Table S3). This indicates that uncertainty in the biological

660 pump, as globally constrained by the available POC flux data, has the potential to

661 vary modern atmospheric $\mathrm{pCO}_{2}$ by approximately $1 / 3$ the range suggested by Kwon et

662 al. [2009], i.e. only a few tens of ppm [-16 ppm, +12 ppm].

663

664 5. Conclusions

665 The Mouw et al. [2016a] dataset is a comprehensive collection of POC flux

666 measurements that allows a regional assessment of the skill of the Martin curve,

667 exponential decay model, and ballast hypothesis parameterizations. When these three 
690 The paucity of high-resolution observations makes it impossible to discern the relative

691 importance of various export mechanisms, many of which are discussed in Section 4.

692 At a given depth level, the Mouw et al. [2016a] dataset shows variability spanning an

parameterizations are compared to observations throughout the water column in 11 biogeochemical provinces we find:

1. Twilight zone observations are captured equally well by the all three parameterizations.

2. Midnight zone observations are captured equally well by the Martin curve and ballast hypothesis.

All three parameterizations would be equally good choices for modeling studies addressing the upper ocean, but only the ballast hypothesis or Martin curve should be selected if export to depths below $1000 \mathrm{~m}$ is of interest.

Parameterizations using the global $b$ value of Martin et al. [1987] were compared with province specific $b$ values of Guidi et al. [2015] and Henson et al. [2012]. Province-specific $b$ values can reduce the bias in the midnight zone POC fluxes in some regions relative to Martin's global $b$ value (Figure 2). However, when all provinces are considered, the interquartile range for each summery statistic overlaps (Figure 5), indicating no global benefit of province-specific $b$ values. Provincespecific $b$ values may still be suitable for studies with a regional focus. For all provinces taken together, the range of Martin's $b$ that best fits data from the midnight zone where long-term carbon sequestration occurs is [0.70, 0.98]. Based on previous global biogeochemical modeling [Kwon et al., 2009], this limited range of $b$ has the capacity to change atmospheric $\mathrm{pCO}_{2}$ by only a few tens of ppm [-16 ppm, $\left.+12 \mathrm{ppm}\right]$. 
693 order of magnitude (Figure 3) that cannot yet be mechanistically explained, and thus

694 cannot yet be accurately modeled. The role of ecosystem structure on export, the

695 biotic and abiotic transformation of particles to different class sizes, and variability

696 through space and time are key areas of research [Burd et al., 2016; Mouw et al.,

$6972016 \mathrm{~b}]$. There is also a great need for seasonally resolved observations at a variety of

698 locations for more complete elucidation and quantification of export mechanisms

$699 \quad$ [Siegel et al. 2016].

700

701 Acknowledgments

702 The authors thank The National Aeronautics and Space Administration (grant \#:

703 NNX11AD59G) and Wisconsin Research Foundation for funding this research. We

704 thank Darren Pilcher for initially setting up the model. Comments from two

705 anonymous reviews greatly improved the manuscript. Data used to create model

706 forcing fields are listed in the references and POC flux data is available at

707 doi:10.5194/essd-2016-22. 


\section{References}

Armstrong, R. A., C. Lee, J. I. Hedges, S. Honjo, and S. G. Wakeham (2002), A new, mechanistic model for organic carbon fluxes in the ocean based on the quantitative association of POC with ballast minerals, Deep Sea Res., Part II, 49(1), 219-236, doi:10.1016/S0967-0645(01)00101-1.

Arnarson, T. S., and R. G. Keil (2005), Influence of organic-mineral aggregates on microbial degradation of the dinoflagellate Scrippsiella trochoidea, Geochimica et Cosmochimica Acta, 69(8), 2111-2117, doi:10.1016/j.gca.2004.11.004.

Banse, K. (1990), New views on the degradation and disposition of organic particles as collected by sediment traps in the open sea, Deep Sea Res., Part A. Oceanographic Res. Papers, 37(7), 1177-1195, doi:10.1016/0198-0149(90)90058-4.

Barange, M., M. Butenschön, A. Yool, N. Beaumont, J. A. Fernandes, A. P. Martin, and J. I. Allen (2017), The cost of reducing the North Atlantic Ocean biological carbon pump, Front. Mar. Sci., 3, 290, doi: 10.3389/fmars.2016.00290.

Behrenfeld, M., and P. Falkowski (1997), Photosynthetic rates derived from satellitebased chlorophyll concentration, Limnol. Oceanogr., 42(1), 1-20, doi:10.4319/1o.1997.42.1.0001.

Berelson, W.M. (2001), The flux of particulate organic carbon into the ocean interior: A comparison of four U.S. JGOFS regional studies, Oceanography, 14(4), 59-67, doi:10.5670/oceanog.2001.07.

Betzer, P. R., W. J. Showers, E. A. Laws, C. D. Winn, G. R. DiTullio, and P. M. Kroopnick (1984), Primary productivity and particle fluxes on a transect of the equator at $153 \mathrm{~W}$ in the Pacific Ocean, Deep Sea Res., Part A. Oceanographic Res. Papers, 31(1), 1-11, doi:10.1016/0198-0149(84)90068-2.

Bopp, L. et al. (2013), Multiple stressors of ocean ecosystems in the 21st century: projections with CMIP5 models. Biogeosciences 10, 6225-6245.

Boyd, P. W., and T. W. Trull (2007), Understanding the export of marine biogenic particles: Is there consensus?, Prog. Oceanogr., 72, 276312,doi:10.4319/1o.1990.35.6.1376.

Boyer, T.P., et al. (2013): World Ocean Database (2013), NOAA Atlas NESDIS 72, S. Levitus, Ed., A. Mishonov, Technical Ed.; Silver Spring, MD, 209pp., doi:10.7289/V5NZ85MT.

Broecker, W. S., and T.-H. Peng (1982), Tracers in the Sea, Eldigio Press, Palisades, N.Y.

Buchanan, P. J., R. J. Matear, A. Lenton, S. J. Phipps, Z. Chase, and D. M. Etheridge (2016), The simulated climate of the Last Glacial Maximum and insights into the global marine carbon cycle, Climate of the Past, 12(12), 2271-2295, doi:10.5194/cp-12-2271-2016.

Buesseler, K. O. (1998), The decoupling of production and particulate export in the surface ocean, Global Biogeochem. Cycles, 12(2), 297-310, doi:10.1029/97GB03366.

Buesseler, K. O., and P. W. Boyd (2009), Shedding light on processes that control particle export and flux attenuation in the twilight zone of the open ocean, Limnol. Oceanogr., 54(4), 1210-1232, doi:10.4319/lo.2009.54.4.1210.

Burd, A. B., and G. A. Jackson (2009), Particle aggregation, Annu. Rev. Mar. Sci., 1, 65-90, doi:10.1146/annurev.marine.010908.163904. 
Burd, A.B., A. Buchan, M. Church, M. Landry, A. McDonnell, U. Passow, D. Steinberg, and H. Benway. (2016), Towards a transformative understanding of the biology of the ocean's biological pump: Priorities for future research, Report of the NSF Biology of the Biological Pump Workshop, February 19-20, 2016 (Hyatt Place New Orleans, New Orleans, LA), 67 pp., doi:10.1575/1912/8263.

Cavan, E. L., F. A. C. Le Moigne, A. J. Poulton, G. A. Tarling, P. Ward, C. J. Daniels, G. M. Fragoso, and R. J. Sanders (2015), Attenuation of particulate organic carbon flux in the Scotia Sea, Southern Ocean, is controlled by zooplankton fecal pellets. Geophys. Res. Lett., 42(3), 821-830, doi:10.1002/2014GL062744.

Cavan, E. L., S. A. Henson, A. Belcher, and R. Sanders (2017), Role of zooplankton in determining the efficiency of the biological carbon pump, Biogeosciences, 14(1), 177-186, doi:10.5194/bg-14-177-2017.

Ciais, P. et al. in Climate Change 2013: The Physical Science Basis. Contribution of Working Group I to the Fifth Assessment Report of the Intergovernmental Panel on Climate Change (eds. Stocker et al.) 1-106 (Cambridge University Press, 2013).

De La Rocha, C. L. (2006), The biological pump, In: Elderfield, H. (Ed.), The oceans and marine geochemistry, 6, 83-111, doi:10.1016/B0-08-043751-6/06107-7.

De La Rocha, C., and U. Passow (2007), Factors influencing the sinking of POC and the efficiency of the biological carbon pump, Deep Sea Res., Part II, 54(5), 639-658, doi:10.1016/j.dsr2.2007.01.004.

De La Rocha, C. L., N. Nowald, and U. Passow (2008), Interactions between diatom aggregates, minerals, particulate organic carbon, and dissolved organic matter: Further implications for the ballast hypothesis, Global Biogeochem. Cycles, 22(4), GB4005, doi:10.1029/2007GB003156.

Deuser, W. G., E. H. Ross, and R. F. Anderson (1981), Seasonality in the supply of sediment to the deep Sargasso Sea and implications for the rapid transfer of matter to the deep ocean, Deep-Sea Res., 28A, 495-505, doi:10.1016/0198-0149(81)90140-0.

Devol, A. H., and H. E. Hartnett (2001), Role of the oxygen-deficient zone in transfer of organic carbon to the deep ocean, Limnol. Oceanogr., 46(7), 1684-1690, doi:10.4319/lo.2001.46.7.1684.

DeVries, T., F. Primeau, and C. Deutsch (2012), The sequestration efficiency of the biological pump, Geophys. Res. Lett., 39, L13601, doi:10.1029/2012GL051963.

DeVries T., and T.S Weber (2017), The export and fate of organic matter in the ocean: New constraints from combining satellite and oceanographic tracer observations, Global Biogeochem. Cycles, 31, doi:10.1002/2016GB005551.

Dunne, J. P., et al. (2013), GFDL's ESM2 global coupled climate-carbon Earth System Models Part II: Carbon system formulation and baseline simulation characteristics, J. Clim., 26(7), 2247-2267, doi:10.1175/JCLI-D-12-00150.1.

Dutkiewicz, S., M. J. Follows, and P. Parekh (2005), Interactions of the iron and phosphorus cycles: A three-dimensional model study, Global Biogeochem. Cycles, 19, GB1021, doi:10.1029/2004GB002342.

Engel, A., J. Szlosek, L. Abramson, Z. F. Liu, and C. Lee (2009), Investigating the effect of ballasting by $\mathrm{CaCO} 3$ in Emiliania huxleyi: I. Formation, settling velocities and physical properties of aggregates, Deep Sea Res., Part II, 56(18), 1396-1407, doi:10.1016/j.dsr2.2008.11.027. 
François, R., S. Honjo, R. Krishfield, and S. Manganini, (2002), Factors controlling the flux of organic carbon to the bathypelagic zone of the ocean, Global Biogeochem. Cycles, 16(4), doi:10.1029/2001GB001722.

Friedrichs, M. A., et al. (2009), Assessing the uncertainties of model estimates of primary productivity in the tropical Pacific Ocean, J. Mar. Syst., 76(1), 113-133, doi:10.1016/j.jmarsys.2008.05.010.

Frouin, R., B. A. Franz, and P. J. Werdell (2002), The SeaWiFS PAR product, In: S.B. Hooker and E.R. Firestone, Algorithm Updates for the Fourth SeaWiFS Data Reprocessing, NASA Tech. Memo. 2003-206892, Volume 22, NASA Goddard Space Flight Center, Greenbelt, Maryland, 46-50.

Giering, S. L., et al. (2014). Reconciliation of the carbon budget in the ocean's twilight zone. Nature, 507(7493), 480-483, doi:10.1038/nature13123.

Giering, S. L. C., R. Sanders, A. P. Martin, S. A. Henson, J. S. Riley, C. M. Marsay, and D. G. Johns (2017), Particle flux in the oceans: Challenging the steady state assumption, Global Biogeochem. Cycles, 31(1), 159-171, doi:10.1002/2016GB005424.

Guidi, L., L. Stemmann, G. A. Jackson, F. Ibanez, H. Claustre, L. Legendre, M. Picheral, and G. Gorsky (2009), Effects of phytoplankton community on production, size, and export of large aggregates: A world-ocean analysis, Limnol. Oceanogr., 54(6), 1951-1963.

Guidi, L., L. Legendre, G. Reygondeau, J. Uitz, L. Stemman, and S. Henson (2015), A new look at ocean carbon remineralization for estimating deepwater sequestration, Global Biogeochem. Cycles, 29, 1044-1059, doi:10.1002/2014GB005063.

Guidi L., et al. (2016), Plankton networks driving carbon export in the oligotrophic ocean, Nature, 532, 465-470, doi:10.1038/nature 16942.

Hauck, J., et al. (2015), On the Southern Ocean CO2 uptake and the role of the biological carbon pump in the 21st century, Global Biogeochem. Cycles, 29, 1451-1470, doi:10.1002/2015GB005140.

Henson, S. A., R. Sanders, E. Madsen, P. J. Morris, F. Le Moigne, and G. D. Quartly (2011), A reduced estimate of the strength of the ocean's biological carbon pump, Geophys. Res. Lett., 38, L04606, doi:10.1029/2011GL046735.

Henson, S. A., R. Sanders, and E. Madsen (2012), Global patterns in efficiency of particulate organic carbon export and transfer to the deep ocean, Global Biogeochem. Cycles, 26, GB1028, doi:10.1029/2011GB004099.

Hofmann, E. E., J. N. Druon, K. Fennel, and M. Friedrichs (2008), Eastern US continental shelf carbon budget integrating models, data assimilation, and analysis, Oceanography, 21(1), 86-104, doi:10.5670/oceanog.2008.70.

Honjo, S., S. J. Manganini, R. A. Krishfield, and R. Francois (2008), Particulate organic carbon fluxes to the ocean interior and factors controlling the biological pump: A synthesis of global sediment trap programs since 1983, Prog. Oceanogr., 76, 217-285, doi:10.1016/j.pocean.2007.11.003.

Howard, M. T., A. M. E. Winguth, C. Klaas, and E. Maier-Reimer (2006), Sensitivity of ocean carbon tracer distributions to particulate organic flux parameterizations, Global Biogeochem. Cycles, 20, GB3011, doi:10.1029/2005GB002499.

Ingalls, A. E., Z. Liu, and C. Lee (2006), Seasonal trends in the pigment and amino acid compositions of sinking particles in biogenic $\mathrm{CaCO} 3$ and $\mathrm{SiO} 2$ dominated regions of the Pacific sector of the Southern Ocean along $170^{\circ} \mathrm{W}$, Deep Sea Res., Part I, 53(5), 836-859, doi:10.1016/j.dsr.2006.01.004. 
Iversen, M. H., and H. Ploug (2010), Ballast minerals and the sinking carbon flux in the ocean: carbon-specific respiration rates and sinking velocity of marine snow aggregates, Biogeosciences, 7(9), 2613-2624, doi:10.5194/bg-7-2613-2010

Iversen, M. H., and M. L. Robert (2015), Ballasting effects of smectite on aggregate formation and export from a natural plankton community, Mar. Chem., 175, 18-27., doi:10.1016/j.marchem.2015.04.009.

Jiao, N., et al. (2010), Microbial production of recalcitrant dissolved organic matter: Long-term carbon storage in the global ocean, Nat. Rev. Microbiol. 8, 593-599, doi:10.1038/nrmicro2386

Jokulsdottir, T. and D. Archer (2016), A stochastic, Lagrangian model of sinking biogenic aggregates in the ocean (SLAMS 1.0): model formulation, validation and sensitivity, Geosci. Model Dev., 9(4), 1455-1476, doi:10.5194/gmd-9-1455-2016

Jolliff, J. K., J. C. Kindle, I. Shulman, B. Penta, M. A. Friedrichs, R. Helber, and R. A. Arnone (2009), Summary diagrams for coupled hydrodynamic-ecosystem model skill assessment, J. Mar. Syst., 76(1), 64-82, doi:10.1016/j.jmarsys.2008.05.014.

Kalnay, E., et al. (1996), The NCEP/NCAR 40-Year Reanalysis Project, Bull. Am. Meteorol. Soc., 77(3), $437-471$, doi:10.1175/1520-0477(1996) 077<0437:TNYRP>2.0.CO;2.

Keil, R. G., J. A. Neibauer, and A. H. Devol (2016), A multiproxy approach to understanding the "enhanced" flux of organic matter through the oxygendeficient waters of the Arabian Sea, Biogeosciences, 13(7), 2077-2092, doi:10.5194/bg-13-2077-2016.

Key, R. M., A. Kozyr, C. L. Sabine, K. Lee, R. Wanninkhof, J. Bullister, R. A. Feely, F. Millero, C. Mordy, and T.-H. Peng (2004), A global ocean carbon climatology: Results from GLODAP, Global Biogeochem. Cycles, 18, GB4031, doi:10.1029/2004GB002247.

Klaas, C., and D. E. Archer (2002), Association of sinking organic matter with various types of mineral ballast in the deep sea: Implications for the rain ratio, Global Biogeochem. Cycles, 16(4), 1116, doi:10.1029/2001GB001765.

Krumhardt, K. M., N. S. Lovenduski, M. C. Long, and K. Lindsay (2016) Avoidable impacts of ocean warming on marine primary production: Insights from the CESM ensembles. Global Biogeochem Cy 31, 114-133

Kwon, E. Y., F. Primeau, and J. L. Sarmiento (2009), The impact of remineralization depth on the air-sea carbon balance, Nat. Geosci., 2(9), 630-635, doi:10.1038/ngeo612.

Kwon, E. Y., J. L. Sarmiento, J. R. Toggweiler, and T. DeVries (2011), The control of atmospheric $\mathrm{pCO} 2$ by ocean ventilation change: The effect of the oceanic storage of biogenic carbon, Global Biogeochem. Cycles, 25, GB3026, doi:10.1029/2011GB004059.

Lam, P. J., S. C. Doney, and J. K. B. Bishop (2011), The dynamic ocean biological pump: Insights from a global compilation of particulate organic carbon, $\mathrm{CaCO} 3$, and opal concentration profiles from the mesopelagic, Global Biogeochem. Cycles, 25, GB3009, doi:10.1029/2010GB003868.

Large, W. G., J. C. McWilliams, and S. C. Doney (1994), Oceanic vertical mixing: A review and a model with a nonlocal boundary layer parameterization, Rev. Geophys., 32, 363-403, doi:10.1029/94RG01872. 
Laufkötter, C., et al. (2015), Drivers and uncertainties of future global marine primary production in marine ecosystem models, Biogeosciences, 12, 6955-6984, doi:10.5194/bg-12-6955-2015

Laws, E. A., P. G. Falkowski, W. O. Smith Jr., H. Ducklow, and J. J. McCarthy (2000), Temperature effects on export production in the open ocean, Global Biogeochem. Cycles, 14(4), 1231 - 1246, doi:10.1029/ 1999GB001229.

Lazzari, P., C. Solidoro, V. Ibello, S. Salon, A. Teruzzi, K. Béranger, S. Colella, and A. Crise (2012), Seasonal and inter-annual variability of plankton chlorophyll and primary production in the Mediterranean Sea: A modelling approach, Biogeosciences, 9(1), 217-233, doi:10.5194/bg-9-217-2012.

Le Moigne, F. A. C., M. Gallinari, E. Laurenceau, and C. L. De La Rocha (2013), Enhanced rates of particulate organic matter degradation by microzooplankton are diminished by added ballast minerals, Biogeosciences, 10, 5755-5765, doi:10.5194/bg-10-5755-2013.

Lebrato, M., K. A. Pitt, A. K. Sweetman, D. O. Jones, J. E. Cartes, A. Oschlies, R. H. Condon, J. C. Molinero, L. Adler, C. Gaillard, and D. Lloris (2012), Jelly-falls historic and recent observations: a review to drive future research directions, Hydrobiologia, 690(1), 227-245, doi:10.1007/s10750-012-1046-8.

Lee, Y. J., P. A. Matrai, M. A. Friedrichs, V. S. Saba, D. Antoine, M. Ardyna, I. Asanuma, M. Babin, S. Bélanger, M. Benoît - Gagné, and E. Devred (2015), An assessment of phytoplankton primary productivity in the Arctic Ocean from satellite ocean color/in situ chlorophyll-a based models, J. Geophys. Res. Oceans, 120(9), 6508-6541, doi:10.1002/ 2015JC011018.

Lima, I. D., P. J. Lam, and S. C. Doney (2014), Dynamics of particulate organic carbon flux in a global ocean model, Biogeosciences, 11(4), 1177-1198, doi:10.5194/bg-11-1177-2014.

Longhurst, A.R. (2006), Ecological Geography of the Sea. $2^{\text {nd }}$ Edition. Academic Press, San Diego, 560p.

Lutz, M. J., R. Dunbar, and K. Caldeira (2002), Regional variability in the vertical flux of particulate organic carbon in the ocean interior, Global Biogeochem. Cycles, 16(3), doi:10.1029/2000GB001383.

Lutz, M. J., K. Caldeira, R. B. Dunbar, and M. Behrenfeld (2007), Seasonal rhythms of net primary production and particulate organic carbon flux to depth describe the efficiency of biological pump in the global ocean, J. Geophys. Res., 112, C10011, doi:10.1029/2006JC003706.

Mahowald, N. M., A. R. Baker, G. Bergametti, N. Brooks, R. A. Duce, T. D. Jickells, N. Kubilay, J. M. Prospero, and I. Tegen (2005), Atmospheric global dust cycle and iron inputs to the ocean, Global Biogeochem. Cycles, 19, GB4025, doi:10.1029/2004GB002402.

Mari, X., U. Passow, C. Migon, A. B. Burd, and L. Legendre (2017), Transparent exopolymer particles: Effects on carbon cycling in the ocean, Prog. Oceanogr., 151, 13-37, doi: 10.1016/j.pocean.2016.11.002.

Marinov, I., A. Gnanadesikan, J. L. Sarmiento, J. R. Toggweiler, M. Follows, and B. K. Mignone (2008a), Impact of oceanic circulation on biological carbon storage in the ocean and atmospheric pCO2, Global Biogeochem. Cycles, 22, GB3007, doi:10.1029/2007GB002958.

Marinov, I., M. Follows, A. Gnanadesikan, J. L. Sarmiento, and R. D. Slater (2008b), How does ocean biology affect atmospheric pCO2? Theory and models, $J$. Geophys. Res., 113, C07032, doi:10.1029/2007JC004598. 
Marshall, J., A. Adcroft, C. Hill, L. Perelman, and C. Heisey (1997a), A finitevolume, incompressible Navier Stokes model for studies of the ocean on parallel computers, J. Geophys. Res., 102(C3), 5753-5766, doi:10.1029/96JC02775.

Marshall, J., C. Hill, L. Perelman, and A. Adcroft (1997b), Hydrostatic, quasihydrostatic, and nonhydrostatic ocean modeling, J. Geophys. Res., 102(C3), 5733-5752, doi:10.1029/96JC02776.

Moore, J. K., S. C. Doney, and K. Lindsay (2004), Upper ocean ecosystem dynamics and iron cycling in a global three-dimensional model, Global Biogeochem. Cycles, 18, GB4028, doi:10.1029/2004GB002220.

Nash, J. E., and J. V. Sutcliffe (1970), River flow forecasting through conceptual models part I-A discussion of principles, Journal of hydrology, 10(3), 282-290, doi:10.1016/0022-1694(70)90255-6.

Pairaud, I. L., J. Gatti, N. Bensoussan, R. Verney, and P. Garreau (2011), Hydrology and circulation in a coastal area off Marseille: validation of a nested 3D model with observations, J. Mar. Syst., 88(1), 20-33, doi:10.1016/j.jmarsys.2011.02.010.

Ploug, H., M. H. Iversen, M. Koski, and E. T. Buitenhuis (2008), Production, oxygen respiration rates, and sinking velocity of copepod fecal pellets: Direct measurements of ballasting by opal and calcite, Limnol. Oceanogr., 53, 469-476, doi:10.4319/lo.2008.53.2.0469.

Pomeroy L. R., and D. Deibel (1986), Temperature regulation of bacterial activity during the spring bloom in newfoundland coastal waters, Science, 233, 359-361, doi:10.1126/science.233.4761.359.

Pomeroy, L. R., W. J. Wiebe, D. Deibel, R. J. Thompson, G. T. Rowe, J. D. Pakulski (1991), Bacterial responses to temperature and substrate concentration during the Newfoundland spring bloom, Mar. Ecol. Prog. Ser., 75, 143-159,

Primeau, F. (2005), Characterizing Transport between the Surface Mixed Layer and $t$ he Ocean Interior with a Forward and Adjoint Global Ocean Transport Model, J. Phys. Oceanogr., 35, 545-564, doi: 10.1175/JPO2699.1.

Marsay, C. M., R. J. Sanders, S. A. Henson, K. Pabortsava, E. P. Achterberg, and R. S. Lampitt (2015), Attenuation of sinking particulate organic carbon flux through the mesopelagic ocean, Proc. Natl. Acad. Sci. U.S.A., 112, 1089-1094, doi:10.1073/pnas.1415311112.

Martin, J. H., G. Knauer, D. Karl, and W. Broenkow (1987), VERTEX: Carbon cycling in the northeast Pacific, Deep Sea Res., 1(34), 267-285, doi:10.1016/0198-0149(87)90086-0.

Mayer, L. M. (1994), Surface area control of organic carbon accumulation in continental shelf sediments, Geochim. Cosmochim. Acta, 58(4), 1271-1284. doi: 10.1016/0016-7037(94)90381-6.

Mouw, C.B. A. Barnett, G. A. McKinley, L. Gloege, and D. Pilcher (2016a), Global ocean particulate organic carbon flux merged with satellite parameters, doi:10.1594/PANGAEA.855600, Supplement to: Mouw, C. B., Barnett, A., McKinley, G. A., Gloege, L., and Pilcher, D. (2016a), Global Ocean Particulate Organic Carbon Flux Merged with Satellite Parameters, Earth System Science Data, 8(2), 531-541, doi:10.5194/essd-8-531-2016.

Mouw, C. B., A. Barnett, G. A. McKinley, L. Gloege, and D. Pilcher (2016b), Phytoplankton size impact on export flux in the global ocean, Global Biogeochem. Cycles, 30, 1542-1562, doi:10.1002/2015GB005355. 
Pabortsava, K., et al. (2017), Carbon sequestration in the deep Atlantic enhanced by Saharan dust, Nat. Geosci., 10(3), 189-194, doi:10.1038/ngeo2899

Pace, M. L., G. A. Knauer, D. M. Karl, J. H. Martin (1987), Primary production, new production and vertical flux in the eastern Pacific Ocean, Nature, 325(6107), 803-804, doi:10.1038/325803a0.

Parekh, P., S. Dutkiewicz, M. J. Follows, and T. Ito (2006), Atmospheric carbon dioxide in a less dusty world, Geophys. Res. Lett., 33, L03610, doi:10.1029/2005GL025098.

Passow, U. (2004), Switching perspectives: Do mineral fluxes determine particulate organic carbon fluxes or vice versa? Geochem. Geophys. Geosyst., 5, Q04002, doi:10.1029/2003GC000670.

Passow, U., and C. L. De La Rocha (2006), Accumulation of mineral ballast on organic aggregates, Global Biogeochem. Cycles, 20, GB1013, doi:10.1029/2005GB002579.

Passow, U., and C. A. Carlson (2012), The biological pump in a high CO2 world, Mar. Ecol. Prog. Ser., 470, 249-271, doi:10.3354/meps09985.

Ragueneau, O., et al. (2000), A review of the Si cycle in the modern ocean: Recent progress and missing gaps in the application of biogenic opal as a paleoproductivity proxy, Global Planet. Change, 26, 317-365.

Saba, V. S., et al. (2010), Challenges of modeling depth-integrated marine primary productivity over multiple decades: A case study at BATS and HOT, Global Biogeochem. Cycles, 24, GB3020, doi:10.1029/2009GB003655.

Saba, V. S., et al. (2011), An evaluation of ocean color model estimates of marine primary productivity in coastal and pelagic regions across the globe, Biogeosciences, 8, 489-503, doi:10.5194/bg-8-489-2011.

Sanders RJ, et al. (2016), Controls over Ocean Mesopelagic Interior Carbon Storage (COMICS): Fieldwork, Synthesis, and Modeling Efforts, Front. Mar. Sci., 3, 136, doi: 10.3389/fmars.2016.00136.

Sarmiento, J.L., and Gruber, N. (2006), Ocean Biogeochemical Dynamics, Princeton University Press, Princeton, N.J.

Schlitzer, R. (2000), Applying the adjoint method for biogeochemical modeling: Export of particulate organic matter in the world ocean, Geophys. Monogr., 114, 107-124, doi:10.1029/GM114p0107.

Schlitzer, R. (2002), Carbon export fluxes in the Southern Ocean: Results from inverse modeling and comparison with satellite-based estimates, Deep Sea Res., Part II., 49, 1623-1644, doi:10.1016/S0967-0645(02)00004-8.

Siegel, D. A., et al. (2016), Prediction of the export and fate of global ocean net primary production: The EXPORTS science plan, Front. Mar. Sci., 3(22), doi:10.3389/fmars.2016.00022.

Sigman, D. M., and E. A. Boyle (2000), Glacial/interglacial variations in atmospheric carbon dioxide, Nature, 407(6806), 859-869, doi:10.1038/35038000.

Smith K. L., Jr., A.D. Sherman, C. L. Huffard, P. R. McGill, R. Henthorn, S. Von Thun, H. A. Ruhl, M. Kahru, M. D. Ohman, (2014), Large salp bloom export from the upper ocean and benthic community response in the abyssal northeast Pacific: Day to week resolution, Limnol. Oceanogr., 59, doi:10.4319/lo.2014.59.3.0745.

Steinberg, D. K., B. A. V. Mooy, K. O. Buesseler, P. W. Boyd, T. Kobari, and D. M. Karl (2008), Bacterial vs. zooplankton control of sinking particle flux in the ocean's twilight zone, Limnol. Oceanogr., 53(4), 1327, doi:10.4319/lo.2008.53.4.1327 
Steinberg, D. K., and M. R. Landry (2017), Zooplankton and the Ocean Carbon Cycle, Ann. Rev. Mar. Sci., 9, 413-444, doi:10.1146/annurev-marine-010814-015924

Stow, C. A., J. Jolliff, D. J. McGillicuddy, S. C. Doney, J. I. Allen, M. A. Friedrichs, K. A. Rose, and P. Wallhead (2009), Skill assessment for coupled biological/physical models of marine systems, J. Mar. Syst., 76(1), 4-15, doi:10.1016/j.jmarsys.2008.03.011.

Suess, E. (1980), Particulate organic carbon flux in the oceans-surface, Nature, 288, 261, doi:10.1038/288260a0.

Taylor, K. E. (2001), Summarizing multiple aspects of model performance in a single diagram, J. Geophys. Res., 106(D7), 7183-7192, doi:10.1029/2000JD900719.

$\mathrm{Yu}, \mathrm{J}$. , et al. (2016), Sequestration of carbon in the deep Atlantic during the last glaciation, Nat. Geosci., 9(4), 319-324, doi:10.1038/ngeo2657.

Van Mooy, B. A. S., R. G. Keil, and A. H. Devol (2002), Impact of suboxia on sinking particulate organic carbon: Enhanced carbon flux and preferential degradation of amino acids via denitrification, Geochim. Cosmochim. Acta, 66, 457-465, doi:10.1016/S0016-7037(01)00787-6

Villa-Alfageme, M., F. C. Soto, E. Ceballos, S. L. C. Giering, F. A. Le Moigne, S. Henson, J. L. Mas, and R. J. Sanders (2016), Geographical, seasonal, and depth variation in sinking particle speeds in the North Atlantic, Geophys. Res. Lett., 43(16), 8609-8616, doi:10.1002/2016GL069233.

VLIZ (2009), Longhurst biogeographical provinces. [Available at http://www.marineregions.org/.]

Volk, T., and M. I. Hoffert (1985), Ocean carbon pumps: Analysis of rela- tive strengths and efficiencies in ocean-driven atmospheric $\mathrm{CO} 2$ changes, Geophys. Monogr. Ser., 32, 99-110, doi:10.1029/GM032p0099.

Walsh, I., J. Dymond, and R. Collier (1988), Rates of recycling of biogenic components of settling particles in the ocean derived from sediment trap experiments. Deep Sea Res., Part A, 35(1), 43-58, doi: 10.1016/0198-0149(88)90056-8

Wilson, J. D., S. Barker, and A. Ridgwell (2012), Assessment of the spatial variability in particulate organic matter and mineral sinking fluxes in the ocean interior: Implications for the ballast hypothesis, Global Biogeochem. Cycles, 26, GB4011, doi:10.1029/2012GB004398.

Yool, A., E. E. Popova, and T. R. Anderson (2011), Medusa-1.0: A new intermediate complexity plankton ecosystem model for the global domain, Geosci. Model Dev., 4, 381-417, doi:10.5194/gmd-4-381-2011. 
1094 Table 1. Annual primary production.

\begin{tabular}{lll}
\hline $\begin{array}{l}\text { Province } \\
\text { [short name] }\end{array}$ & $\begin{array}{l}\mathrm{VGPM}^{\dagger, \dagger} \\
{\left[\mathrm{g} \mathrm{m}^{-2}\right]}\end{array}$ & $\begin{array}{l}\text { Simulation }^{\dagger} \\
{\left[\mathrm{g} \mathrm{m}^{-2}\right]}\end{array}$ \\
\hline NPSW & $96 \pm 53$ & $137 \pm 1$ \\
PSAW & $148 \pm 55$ & $113 \pm 113$ \\
SPSG & $108 \pm 29$ & $71 \pm 34$ \\
NADR & $251 \pm 88$ & $249 \pm 100$ \\
NASW & $113 \pm 23$ & $134 \pm 2$ \\
NPPF & $202 \pm 61$ & $230 \pm 140$ \\
PNEC & $128 \pm 37$ & $118 \pm 58$ \\
PEQD* & $155 \pm 53$ & $114 \pm 58$ \\
ANTA & $51 \pm 31$ & $39 \pm 49$ \\
SANT & $100 \pm 59$ & $83 \pm 88$ \\
PSAE* $^{*}$ & $148 \pm 45$ & $108 \pm 99$ \\
\hline
\end{tabular}

* indicates province is presented in the main text.

$1096 \uparrow$ Uncertainty is one standard deviation.

$1097+$ VGPM is satellite-observed net primary production. 
Table 2. Definition of equation parameters.

\begin{tabular}{|c|c|c|}
\hline Parameter & Units & Definition \\
\hline $\mathrm{F}(\mathrm{z})$ & $\mathrm{mgC} \mathrm{m} \mathrm{m}^{-2} \mathrm{~d}^{-1}$ & POC flux \\
\hline$[\mathrm{POC}(\mathrm{z})]$ & $\mathrm{mgC} \mathrm{m}{ }^{-3}$ & Volume concentration of labile POC \\
\hline$\left[\mathrm{POC}_{\mathrm{Y}}(\mathrm{z})\right]$ & $\mathrm{mgC} \mathrm{m} \mathrm{m}^{-3}$ & Volume concentration of POC associated with Y \\
\hline$\left[\mathrm{POC}_{\mathrm{Y}}^{\mathrm{hard}}(\mathrm{z})\right]$ & $\mathrm{mgC} \mathrm{m}{ }^{-3}$ & $\begin{array}{l}\text { Volume concentration of POC associated with Y } \\
\text { in the hard subclass }\end{array}$ \\
\hline$\left[\operatorname{POC}_{Y}^{\text {Soft }}(z)\right]$ & $\mathrm{mgC} \mathrm{m}{ }^{-3}$ & $\begin{array}{l}\text { Volume concentration of POC associated with Y } \\
\text { in the soft subclass }\end{array}$ \\
\hline$\left[X^{p r o d}(z)\right]$ & $\mathrm{mgC} \mathrm{m}^{-3}$ & Volume concentration of production of $\mathrm{X}$ \\
\hline$P_{X}^{\text {prod }}(z)$ & $\mathrm{mgC} \mathrm{m}{ }^{-3} \mathrm{~d}^{-1}$ & Production of $\mathrm{X}$ at depth $\mathrm{z}$ by phytoplankton \\
\hline$Z_{X}^{\text {prod }}(z)$ & $\mathrm{mgC} \mathrm{m} \mathrm{m}^{-3} \mathrm{~d}^{-1}$ & Production of $X$ at depth $\mathrm{z}$ by zooplankton \\
\hline$w_{X}$ & $\mathrm{~m} \mathrm{~d}^{-1}$ & Sinking speed of $X$ \\
\hline$w_{\text {dust }}$ & $\mathrm{m} \mathrm{d}^{-1}$ & Sinking speed of dust \\
\hline$k_{X}=\frac{w_{X}}{\lambda_{X}}$ & $d^{-1}$ & Remineralization rate of $X$ \\
\hline$k_{Y}^{\text {hard }}=\frac{w_{Y}}{\lambda_{\text {hard }}}$ & $\mathrm{d}^{-1}$ & Remineralization rate of hard subclass for $\mathrm{Y}$ \\
\hline$\lambda_{X}$ & $\mathrm{~m}$ & Remineralization length scale of $\mathrm{X}$ \\
\hline$\lambda_{\text {hard }}$ & $\mathrm{m}$ & Remineralization length scale of hard subclass \\
\hline$\omega_{Y}$ & $\mathrm{gC} \mathrm{gY}^{-1}$ & POC carrying capacity of $Y$ \\
\hline$f_{Y}^{\text {hard }}$ & dimensionless & Fraction of Y routed to hard subclass \\
\hline$d u s t^{d e p}$ & mgDust $\mathrm{m}^{-2} \mathrm{~d}^{-1}$ & Surface dust deposition \\
\hline$\Delta z_{\text {surf }}$ & $\mathrm{m}$ & Depth of surface grid cell \\
\hline$b$ & dimensionless & Flux attenuation parameter \\
\hline
\end{tabular}

$\mathrm{X}=$ POC, PIC, or opal

$1101 \quad \mathrm{Y}=\mathrm{PIC}$, opal, or dust 
1103 Table 3: Tendency equation for POC associated with PIC at depth z $\left(\frac{d\left[\operatorname{POC}_{P I C}(z)\right]}{d t}\right)$.

1104 The summation of the parameter column produces the full tendency equation.

1105

Definition

$\omega_{P I C} f_{P I C}^{\text {hard }}\left(\frac{d\left[\text { PIC }^{\text {prod }}(z)\right]}{d t}\right) \quad$ Tendency of hard POC associated with PIC

$\omega_{P I C}\left(1-f_{P I C}^{\text {hard }}\right)\left(\frac{d\left[\text { PIC }^{\text {prod }}(z)\right]}{d t}\right) \quad$ Tendency of soft POC associated with PIC

$w_{P I C}\left(\frac{d\left[P O C_{P I C}^{\text {hard }}(z)\right]}{d z}\right) \quad$ Sinking of hard POC associated with PIC

$w_{P I C}\left(\frac{d\left[P O C_{P I C}^{s o f t}(z)\right]}{d z}\right) \quad$ Sinking of soft POC associated with PIC

$-k_{P I C}^{\text {hard }}\left[\operatorname{POC}_{P I C}^{\text {hard }}(z)\right] \quad$ Remineralization of hard POC associated with PIC

$-k_{P I C}\left[P O C_{P I C}^{\text {soft }}(z)\right] \quad$ Remineralization of soft POC associated with PIC 
1108 Table 4: Tendency equation for POC associated with opal at depth $\mathrm{z}\left(\frac{d\left[\text { POC }_{\text {opal }}(\mathrm{z})\right]}{d t}\right)$.

1109 The summation of the parameter column produces the full tendency equation.

1110

Definition

$$
\begin{array}{ll}
\omega_{\text {opal }} f_{\text {opal }}^{\text {hard }}\left(\frac{d[\text { opal }}{\text { prod }(z)]}\right) & \text { Tendency of hard POC associated with opal } \\
\omega_{\text {opal }}\left(1-f_{\text {opal }}^{\text {hard }}\right)\left(\frac{d\left[\text { opal }^{\text {prod }}(z)\right]}{d t}\right) & \text { Tendency of soft POC associated with opal } \\
w_{\text {opal }}\left(\frac{d\left[P O C_{\text {opal }}^{\text {hard }}(z)\right]}{d z}\right) & \text { Sinking of hard POC associated with opal } \\
w_{\text {opal }}\left(\frac{d\left[P O C_{\text {opal }}^{\text {soft }}(z)\right]}{d z}\right) & \text { Sinking of soft POC associated with opal } \\
-k_{\text {opal }}^{\text {hard }}\left[\operatorname{POC}_{\text {opal }}^{\text {hard }}(z)\right] & \text { Remineralization of hard POC associated with opal } \\
-f_{T} k_{\text {opal }}\left[\operatorname{POC}_{\text {opal }}^{\text {soft }}(z)\right] &
\end{array}
$$

$1111 \quad \overline{f_{T} \text { is the temperature-dependency function [supplementary Table S3] }}$

1112 
1113 Table 5: Tendency equation for POC associated with dust at depth $\mathrm{z}\left(\frac{d\left[\mathrm{POC}_{d u s t}(\mathrm{z})\right]}{d t}\right)$.

1114 The summation of the parameter column produces the full tendency equation.

1115

Parameter Definition

$$
\begin{aligned}
& \omega_{\text {dust }} f_{\text {dust }}^{\text {hard }}\left(\frac{\text { dust }^{\text {dep }}}{\Delta z_{\text {surf }}}\right) \\
& \omega_{\text {dust }}\left(1-f_{\text {dust }}^{\text {hard }}\right)\left(\frac{d u s t^{\text {dep }}}{\Delta z_{\text {surf }}}\right) \\
& w_{\text {dust }}\left(\frac{d\left[P O C_{\text {dust }}^{\text {hard }}(z)\right]}{d z}\right) \\
& w_{\text {dust }}\left(\frac{d\left[P O C_{d u s t}^{\text {soft }}(z)\right]}{d z}\right) \\
& -k_{\text {dust }}^{\text {hard }}\left[P O C_{d u s t}^{\text {hard }}(z)\right] \\
& -k_{\text {dust }}\left[P O C_{\text {dust }}^{\text {soft }}(z)\right]
\end{aligned}
$$

Tendency of hard POC associated with dust

Tendency of soft POC associated with dust

Sinking of hard POC associated with dust

Sinking of soft POC associated with dust

Remineralization of hard POC associated with dust

Remineralization of soft POC associated with dust

1116

1117 
1118 Table 6: Tendency equation for labile POC at depth $\mathrm{z}\left(\frac{d[P O C(z)]}{d t}\right)$ used in the ballast 1119 model. The summation of the parameter column produces the full tendency equation. 1120

$$
\begin{array}{ll}
\text { Parameter } & \text { Definition } \\
\hline\left(\frac{d\left[\text { POC }^{\text {prod }}(z)\right]}{d t}\right) & \text { Tendency of POC production by phytoplankton and zooplankton } \\
-\omega_{P I C}\left(\frac{d\left[\text { PIC }^{\text {prod }}(z)\right]}{d t}\right) & \text { Tendency of POC associated with PIC production } \\
-\omega_{\text {opal }}\left(\frac{d[\text { opal }}{d t}{ }^{\text {prod }}(z)\right] \\
-\omega_{d u s t}\left(\frac{d u s t^{\text {dep }}}{\Delta z_{\text {surf }}}\right) & \text { Tendency of POC associated with opal production } \\
w_{\text {poc }}\left(\frac{d[P O C(z)]}{d z}\right) & \text { Tendency of POC associated with dust deposition } \\
-f_{T} k_{\text {poc }}[P O C(z)] & \text { Sinking of labile POC }
\end{array}
$$

$1121 \quad f_{T}$ is the temperature-dependency function [supplementary Table S3] 
Figure 1. Simulated provinces presented in the paper are shown in dark gray. Light gray provinces are presented in supplementary. Red dots are locations of flux observations from sediment traps and thorium-234 depletion.

Figure 2. Target diagrams displaying average model skill at each region (SANT, PEQD, PSAE, NADR) for the Martin et al. [1987] global $b$ value (Martin), Henson et $a l$. [2012] regional $b$ values (Henson), and Guidi et al. [2015] regional $b$ values (Guidi) in the twilight zone (red) and midnight zone (blue). The black circle is the normalized standard deviation of the observed POC flux. Symbols within the circle indicate that the parameterization captures the observed POC flux more accurately than using the mean of the observed data (modeling efficiency $>0$ ) at each region.

Figure 3. Simulated POC flux (black) with standard deviation (gray) compared with observed POC flux (blue) for the Martin curve (column 1), exponential model (column 2), and ballast model (column 3) at four provinces (SANT, PEQD, PSAE, NADR). Depth is relative to the surface. Twilight zone extends from $100 \mathrm{~m}-1000 \mathrm{~m}$ and midnight zone is $>1000 \mathrm{~m}$.

Figure 4. Cross plot of simulated POC flux versus observed POC flux for the Martin curve, exponential model, and ballast model at four provinces (SANT, PEQD, PSAE, NADR). Colors represent depth below surface: the upper twilight zone (100-500m), lower twilight zone (500-1000m), upper midnight zone (1000-2500m), and lower midnight zone $(2500-4000 \mathrm{~m})$. The reliability index (RI) for each zone is indicated at top left in each panel.

Figure 5. Box and whisker plots of summary statistics in the twilight zone (red) and midnight zone (blue) for each parameterization (Exponential, Ballast, Martin et al. [1987] global $b$ value, Henson et al. [2012] regional $b$ values, and Guidi et al. [2015] regional $b$ values). These box and whisker plots account for all simulated provinces (11 total).

Figure 6. Target diagrams displaying average model skill at each region (SANT, PEQD, PSAE, NADR) for the exponential model, Martin curve, and ballast model in the twilight zone (red) and midnight zone (blue). The black circle is the normalized standard deviation of the observed POC flux. Symbols within the circle indicate that the parameterization captures the observed POC flux more accurately than using the mean of the observed data (Modeling Efficiency $(\mathrm{ME})>0$ ) at each region.

Figure 7. Simulated POC flux (black) with standard deviation (gray) compared with observed POC flux (blue) using the global $b$ value of Martin et al. [1987] (column 1), regional $b$ value of Henson et al. [2012] (column 2), and regional $b$ values of Guidi et al. [2015] (column 3) at four provinces (SANT, PEQD, PSAE, NADR). Depth is relative to the surface. Twilight zone extends from $100 \mathrm{~m}-1000 \mathrm{~m}$ and midnight zone is $>1000 \mathrm{~m}$.

Figure 8. Cross plot of simulated POC flux versus observed POC flux using the global $b$ value of Martin et al. [1987], Henson et al. [2012] regional b values, and Guidi et al. [2015] regional $b$ values at four provinces (SANT, PEQD, PSAE, NADR). Colors represent depth below surface: the upper twilight zone (100-500m), 
1173 lower twilight zone (500-1000m), upper midnight zone (1000-2500m), and lower 1174 midnight zone (2500-4000m). The reliability index (RI) for each zone is indicated at top left in each panel.

Figure 9. A: Range of $b$ values for each province. Light gray bar uses data in the twilight and midnight zone while dark bars only use data in the midnight zone. B: percentage of observations in the midnight zone for each province. C: Histogram of normalized occurrence of $b$ values fit to observations in the twilight and midnight zone D: Histogram of normalized occurrence of $b$ values fit to observations in the twilight and midnight zone. Red line is at Martin et al. [1987] global $b$ value of 0.858 . Dotted lines are the $25^{\text {th }}$ percentile and $75^{\text {th }}$ percentile. Solid black line is the median.

$1184 \Delta \mathrm{pCO}_{2}$ is relative to $\mathrm{pCO}_{2}$ with $\mathrm{b}=0.858$ [Kwon et al., 2009]. 